\title{
Motoren bag indisk nationalisme
}

\section{Ashis Nandy}

\section{Mindreværd og angst driver nationalismen}

Der er tre bekymringer, som har plaget os i Indien siden midten af 1980 'erne. Den første er den mindskede rolle for det hellige i dagliglivet, selv om Indien stadig har en overflod af religioner og ritualer. Indiske religioner er organiseret omkring et utal af religiøse retninger, familiepræster, særlige landsby- og familieguder, pilgrimrejser og manatsa helligdomme, altsammen overvejende lokalt og regionalt.

Den traditionelle religiøse følsomhed, der bygger på de traditioner, er blevet stadig mindre bæredygtig $\mathrm{i}$ takt med, at folk er flyttet fra land til by, fra delstat til delstat og fra én sprogzone til en anden. Den nye rodløshed har skabt behov for en mere fælles version af troen, hvor en person, der flytter fra Kerala til Uttar Pradesh kan fortsætte med at føle sig som del af sin religion. Omsiggribende sekularisering har fremmet frygten for at miste troen.

Den anden bekymring er produkt af urbaniseringen. Teknisk set er Indien stadig et landsamfund, men ur- bane normer, livsstil og smag er begyndt at gøre sig gældende på en måde, der ville have været utænkelig for blot to årtier siden. Byerne har givet individet mulighed for at forsvinde og genopfinde sig selv i omgivelser af anonymitet og upersonlighed. Men den anonyme upersonlighed kræver en form for individualisme og evne til at leve med den ensomhed, der vokser ud af svækkede familie- og kastebånd. Hvis du er indvandrer til byen i første generation, vil du se tilbage på det liv og de sociale relationer, som du har ladt bag dig, med nostalgi. Og du vil lede efter den tabte følelse af at høre til.

Den tredje bekymring er, at Indiens middelklasse siden 1830'erne konstant har været påvirket af en form for moderne uddannelse, som har været underlagt et globalt kulturhierarki. Middelklassen er bibragt en tro på, at vestlige samfund er moderne, mens Indien er præmoderne og tilbagestående. Forskellen imellem vestliggørelse og modernisering er ikke trængt ind hos 
hovedparten af vestligt uddannede indere, som er overbeviste om, at deres fremtid ligger $i$ at blive nøjagtig som europæerne og amerikanerne.

Lad jer ikke påvirke af radikal retorik. Hvis du undersøger, hvor de fleste af vores venstreorienterede og nationalistiske Swadeshi wallahs sender deres børn hen for at studere, vil du finde forbløffende lille forskel på deres handling og resten af det indiske borgerskabs. Moderne indere er uundgåeligt kommet til at leve med en dyb følelse af utilstrækkelighed. De søger lighed, ikke med andre asiatiske lande, der klarer sig godt, men med selveste Vesten.

Sidste år viste et studium, at inderne er det mest nationalistiske folk i verden. De overgår borgerne i lande som USA, Japan og Pakistan, og deres nationalisme er drevet frem af en dyb følelse af underlegenhed. Den eneste gruppe af politiske aktører, der har svaret på de bekymringer, er hindunationalisterne, selv om deres tætte konkurrenter, de islamiske fundamentalister, også er kommet tæt på at reagere på disse bekymringer. Ingen af dem har imidlertid gjort det bevidst; de er for indskrænkede til at identificere det psykologiske rum, som de optager. De har gjort det intuitivt og har høstet frugterne af det, som de har gjort.

I de første 40 år af indisk uafhængighed lå vælgerbasen for hindunationalister groft sagt mellem syv og ni pct. Denne base er øget til mere end 20 pct. Denne opbakning er uforholdsmæssigt højere i den urbane mellemklasse og blandt uddannede, moderne indere.

Jeg ville ikke blive overrasket, hvis undersøgelser viser, at blandt indere, der ikke er lokale statsborgere, er støttegrundlaget for hindunationalisme over 90 pct. Den base vil nok ikke øges meget mere, men den kan allerede nå langt i indisk politik i dag i betragtning af det fragmenterede rum for partier.

Den demokratiske proces i Indien har bragt mange sociale grupper, som for 30 år siden ikke kunne drømme om at nærme sig magten, tættere på netop magten. Men i processen for at skabe en nationalstat ved navn Indien har samme proces sikret, at de som er tæt på den indiske stat, har taget statens globale og homogeniserende budskab til sig.

En del af dette budskab er, at hvis du vil have succes som nationalstat på den globale arena, må du gøre dét ved din kulturelle forskellighed, dine minoriteter, skovboere og stammer som Europa, Nordamerika og Australien har gjort ved sine. Det ser hindunationalisterne ud til at være godt rustet og velkvalificerede til at gøre.

Ashis Nandy er Indiens nok mest anerkendte politiske sociolog.Denne kommentar har varet bragt $i$ det indiske ugemagasin Tehelka.

Oversat fra engelsk af Vibeke Sperling. 